\title{
Faktor-Faktor Yang Mempengaruhi Pendapatan Usaha Tani Padi Ciherang Di Desa Tebing Tinggi Kabupaten Serdang Bedagai
}

\author{
Faoeza Hafiz Saragih ${ }^{*}$ \\ Faisal Azhari Baldan Panjaitan ${ }^{2}$ \\ 1Program Studi Agribisnis Fakultas Pertanian Universitas Samudra \\ 1Program Studi Agribisnis Fakultas Pertanian Universitas Al-Wasliyah Medan \\ *email:hafizsaragih@unsam.ac.id \\ Diterima: Maret 2020, Disetujui: April 2020, Dipublish: April 2020
}

\begin{abstract}
Abstrak
Petani padi sebagai pengelola usaha tani sampai saat ini belum mendapatkan hasil dan pendapatan yang diharapkan baik dari sisi petani itu sendiri maupun dari pemerintah. Penelitian ini bertujuan untuk mengetahui kelayakan usaha tani padi dan faktor-faktor yang mempengaruhi pendapatan usaha tani padi di Desa Tebing Tinggi Kabupaten Deli Serdang. Alasan pemilihan lokasi ini dikarenakan desa ini merupakan penerima bantuan benih dari Sekolah Lapangan Pertanian Tanaman Terpadu dimana terdapat 160 petani yang menggunakan benih Ciherang. Jumlah petani yang dijadikan sampel dalam penelitian ini adalah 40 petani dan variabel yang diuji adalah biaya tenaga kerja, biaya pupuk phonska, biaya pupuk SP, biaya pupuk $\mathrm{KCl}$, biaya pestisida, luas lahan, biaya pupuk urea, biaya pupuk ZA dan harga benih. Hasil penelitian menunjukkan bahwa usahatani memiliki R/C ratio sebesar 3,27 yang menunjukkan bahwa usaha tani ini layak. Sedangkan variabel biaya tenaga kerja, biaya pupuk $\mathrm{KCl}$ dan biaya pupuk urea berpengaruh signifikan terhadap pendapatan usaha tani padi, sedangkan variabel lain tidak berpengaruh. Subsidi pupuk dan bantuan benih merupakan kebijakan pemerintah yang sangat meringankan petani dalam pembiayaan usaha taninya sehingga kebijakan ini harus terus dijalankan dan diawasi dalam pelaksanaannya dalam upaya peningkatan pendapatan petani padi.
\end{abstract}

Kata Kunci: Padi, Pendapatan, Pupuk, Tenaga Kerja, Benih

\begin{abstract}
Up to now, paddy farmers as farm managers have not received the expected results and income from both the farmers themselves and the government. This study aims to determine the factors that influence rice farming income in Tebing Tinggi Village, Deli Serdang Regency. The reason for choosing this location is because this village is the recipient of seed aid from SLPTT where there are 160 farmers using Ciherang seeds. The number of farmers sampled in this study were 40 farmers and the variables tested were labor costs, phonska fertilizer costs, SP fertilizer costs, $\mathrm{KCl}$ fertilizer costs, pesticide costs, land area, urea fertilizer costs, ZA fertilizer costs and seed prices. The results showed that feasibility of farm bussiness has $R / C$ ratio was 3,28 its mean the farm business was feasible labor costs, KCl fertilizer costs and urea fertilizer costs had a significant effect on rice farming income, while other variables had no effect. Fertilizer subsidies and seed assistance are government policies that greatly relieve farmers in financing their farming business so that this policy must continue to be carried out and monitored in its implementation in an effort to increase the income of rice farmers.
\end{abstract}

Keywords: Rice, Income, Fertilizer, Labor, Seed 


\section{PENDAHULUAN}

Indonesia adalah negara yang berkembang yang terus melaksanakan pembangunan di segala sektor dimana salah satu bidang yang menjadi prioritas pembangunan adalah sektor pertanian. Sektor pertanian telah sejak lama menjadi sektor yang penting dalam sejarah pembangunan di Indonesia dalam upaya mengurangi kemiskinan baik secara langsung maupun tidak langsung terutama dalam peningkatan kesejahteraan petani (Ma'ruf,M.I., dkk., 2019)

Tujuan utama dalam pembangunan pertanian adalah peningkatan kesejahteraan petani dengan berbagai upaya khusus yang telah di lakukan pemerintah terutama usahatani padi (Ratri, dkk., 2019). Padi merupakan tanaman penting bagi masyarakat Indonesia karena padi merupakan penghasil beras yang merupakan bahan pangan konsumsi pokok bagi sebahagian besar masyarakat Indonesia. Oleh karena itu padi merupakan tumpuan utama dalam ketahanan pangan nasional (Keukama, M.F., dkk, 2017). Dalam beberapa tahun terakhir Kementrian Pertanian telah menjalankan program Upaya Khusus Padi, Jagung, Kedelai (Upsus Pajale) di beberapa provinsi sentra tanaman tersebut untuk mencapai swasembada pangan.

Salah satu strategi dalam mendukung program Upsus Pajale adalah penerapan Sekolah Lapangan Pertanian Tanaman Terpadu (SLPTT) adalah penggunaan benih bersertifikat dalam upaya untuk mencapai target produksi yang diinginkan (Ratri M. dan Yuliawati, 2018). Hal ini sebagai bagian dari target program Peningkatan Produksi Beras Nasional (P2BN) dimana Kementrian Pertanian melalui Badan Pengembangan dan Penelitian Pertaninan (Balitbangtan) yang telah mengeluarkan rekomendasi penggunaan benih bersertifikat (Zen, I., 2017). Dalam upaya mendukung kebijakan ini maka pemerintah memberikan kebijakan insentif input produksi dengan melakukan subsidi benih dengan tingkat harga yang diharapkan sesuai dengan petani. Dimana dengan harga yang murah dan terjangkau, benih memiliki kualitas yang baik sehingga dapat meningkatkan produksi dan pendapatan petani (Riefqi, A.R., dkk., 2017).

Dalam penelitiannya Astuti (2017) tinggi produksi dan produktivitas usahatani padi sawah disebabkan faktor-faktor produksi yang telah dapat dikelola dengan baik oleh petani. Namun tingginya produksi dan produktivitas belum tentu pendapatan petani akan tinggi pula karena hal ini dapat dipengaruhi faktor harga sarana produksi. Provinsi Sumatera Utara adalah salah satu provinsi di Indonesia yang merupakan produsen padi. Kabupaten di Provinsi Sumatera Utara yang memberikan kontribusi produksi luas panen padi sawah adalah Kabupaten Simalungun, Kabupaten Deli Serdang, Kabupaten Langkat dan Kabupaten Serdang 
Bedagai. Kabupaten Serdang Bedagai memiliki luas panen $75.816 \mathrm{Ha}$ dengan produksi 425.946,2 ton (BPS Serdang Bedagai, 2017).

Dari 17 kecamatan yang ada di Kabupaten Serdang Bedagai terdapat 5 kecamatan yang memiliki produksi terbesar yaitu Perbaungan, Sei Bamban, Pantai Cermin, Tanjung Beringin dan Teluk Mengkudu. Namun dari 5 kecamatan tersebut yang mendapatkan bantuan benih langsung dari program SLPTT adalah Kecamatan Tanjung Beringin karena dianggap sangat berpotensi untuk peningkatan produksi padi. Salah satu desa yang mendapatkan bantuan benih sepanjang lima tahun adalah Desa Tebing Tinggi berdasarkan Dinas Pertanian Kabupaten Serdang Bedagai.

Dengan bantuan benih ini diharapkan akan dapat meningkatkan pendapatan usaha tani padi dengan varietas ciherang. Pendapatan usaha tani merupakan bagian yang penting untuk diperhatikan karena pendapatan petani sangat menyangkut dengan tingkat kesejahteraannya. Oleh karena itu dalam penelitian ini akan dilihat kelayakan usaha tani dan faktorfaktor yang mempengaruhi pendapatan usaha tani nya.

\section{METODE PENELITIAN}

Penelitian ini dilakukan di Desa Tebing Tinggi Kecamatan Tanjung Beringin Kabupaten Serdang Bedagai secara purposive. Desa Tebing Tinggi sepanjang 5 tahun 2012-2016 masuk dalam desa yang menerima bantuan langsung benih unggul Sekolah Lapangan Pola Tanaman Terpadu (SLPTT). Jumlah kelompok tani di Desa Tebing Tinggi sebanyak 14 kelompok tani dengan jumlah petani sebanyak 302 orang. Adapun jumlah petani yang menggunakan bibit Ciherang sebanyak 160 orang dan sampel yang digunakan 20\% dari total populasi sehingga jumlah sampel sebanyak 40 orang petani.

Untuk menghitung kelayakan usaha tani padi maka penelitian ini digunakan perhitungan $\mathrm{R} / \mathrm{C}$ ratio dengan rumus:

$$
R / C_{\text {ratio }}=\frac{T R}{T C}
$$

Dimana :

$$
\begin{array}{ll}
\mathrm{TR} & =\text { Total Revenue (Rp) } \\
\mathrm{TC} & =\text { Total Cost (Rp) }
\end{array}
$$

Dengan kriteria apabila:

$\mathrm{R} / \mathrm{C}$ ratio > 1, maka usaha tani dikatakan layak,

$\mathrm{R} / \mathrm{C}$ ratio $=1$, maka usaha tani dikatakan impas, dan

$\mathrm{R} / \mathrm{C}$ ratio < 1, maka usaha tani dikatakan tidak layak.

(Soekartawi, 1984)

Untuk melihat faktor yang mempengaruhi pendapatan usaha tani Ciherang di Desa Tebing Tinggi digunakan analisis regresi liner berganda. Adapun model matematis dari persamaan tersebut adalah sebagai berikut:

$$
\begin{gathered}
Y=a+b_{1} x_{1}+b_{2} X_{2}+b_{3} X_{3}+b_{4} X_{4}+b_{5} X_{5} \\
+b_{6} X_{6}+b_{7} X_{7}+b_{8} X_{8}+\mu
\end{gathered}
$$

Dimana

$\mathrm{Y}=$ Pendapatan $(\mathrm{Rp} / \mathrm{MT})$

$\mathrm{X}_{1}$ = Biaya Tenaga Kerja (Rp/MT)

$\mathrm{X}_{2}$ = Biaya Pupuk Phonska (Rp/SAK) 
$\mathrm{X}_{3}=$ Biaya Pupuk SP (Rp/SAK)

$\mathrm{X}_{4}=$ Biaya Pupuk KCl (Rp/SAK)

$\mathrm{X}_{5}=$ Biaya Pestisida (Rp/Liter)

$\mathrm{X}_{6}=$ Luas Lahan $(\mathrm{Ha})$

$\mathrm{X}_{7}=$ Biaya Pupuk Urea $(\mathrm{Rp} / \mathrm{SAK})$

$\mathrm{X}_{8}=$ Biaya Pupuk ZA (Rp/SAK)

$\mathrm{X}_{9}=$ Biaya Benih $(\mathrm{Rp} / \mathrm{Kg})$

\section{HASIL DAN PEMBAHASAN}

Struktur usaha tani padi Ciherang mencakup struktur produksi, biaya dan pendapatan petani yang didapat dalam satu musim tanam. Dimana secara umum struktur biaya dalam usaha tani terbagi dua yaitu biaya tetap dan biaya variabel. Rata-rata biaya variabel yang banyak dikeluarkan petani adalah sebesar Rp. 9.378.916/Ha dengan biaya terbesar yang dikeluarkan adalah biaya tenaga kerja yaitu rata-rata sebesar Rp. 6.529.164/Ha, sedangkan rata-rata biaya tetap yang dikeluarkan adalah sebesar Rp. 2.039.358/Ha. Harga gabah yang diterima petani bervariasi yaitu sekitar Rp.4.700 - Rp. 4.900/Kg nya dengan rata-rata harga yaitu Rp. $4.700 / \mathrm{Kg}$.

Untuk menghitung besarnya pendapatan yang diterima petani dan kelayakan usaha tani dengan $\mathrm{R} / \mathrm{C}$ ratio dapat dilihat pada tabel berikut:

Tabel 1. Perhitungan pendapatan dan $\mathrm{R} / \mathrm{C}$ ratio usaha tani Ciherang

\begin{tabular}{ccr}
\hline No & Uraian & \multicolumn{1}{c}{ Jumlah } \\
\hline 1 & Produksi (Kg/Ha) & 7.928 \\
2 & Harga gabah (Rp) & 4.715 \\
& Penerimaan (Rp) & $37.378 .162,5$ \\
3 & Total biaya tetap (Rp) & 2.039 .358 \\
4 & Total biaya variabel (Rp) & 9.378 .916 \\
& Total biaya (Rp) & 11.418 .274 \\
\hline & Pendapatan (Rp) & 25.959 .888 .5 \\
\hline & R/C ratio & 3.27 \\
\hline
\end{tabular}

Sumber: data primer (2018) diolah

Berdasarkan tabel diatas dapat diketahui bahwa nilai $\mathrm{R} / \mathrm{C}$ ratio dari usaha tani padi Ciherang lebih besar dari pada 1 yang menunjukkan bahwa usaha tani ini layak diusahakan dan berarti bahwa setiap biaya total yang dikeluarkan sebesar Rp. 1,00 akan menghasilkan penerimaan sebesar Rp. 3,27. Besarnya pendapatan yang diterima petani rata-rata sebesar Rp. 25.959.88,5/Ha, sehingga petani dapat dikatakan memperoleh pendapatan yang besar dalam satu musim tanam per hektarnya. Luas lahan yang dimiliki petani sampel rata-rata sebesar $2 \mathrm{Ha}$, dengan luas lahan terkecil yaitu 0,5 Ha dan luas lahan terbesar 5 Ha. Namun berdasarkan penelitian yang dilakukan oleh Purba, $\mathrm{R}$ dan Y. Giametri (2017) di Provinsi Banten, bahwa varietas Ciherang dan Mekongga secara finansial kurang menguntungkan bila dibandingkan dengan varietas Inpari-19. Walau demikian saat ini dengan adanya bantuan dari pemerintah terkait benih bersertifikat usaha tani di Desa Tebing 
Tinggi masih dapat dikatakan layak untuk diusahakan.

Disamping itu Munizar dan Tangakesalu (2019) dalam penelitiannya mengungkapkan bahwa tingginya produksi yang didapatkan petani dalam usaha taninya dari luas lahan yang diusahakan belum menjamin petani akan mendapatkan pendapatan yang tinggi pula. Hal ini bergantung pada harga jual yang diterima petani dan biaya-biaya yang telah di keluarkan dalam usaha taninya. Besarnya keuntungan yang didapatkan petani juga tidak lepas dari berkurangnya biaya pupuk dan biaya benih yang dikeluarkan. Dengan adanya bantuan dari pemerintah biaya benih dan biaya pupuk terutama pupuk urea yang merupakan pupuk subsidi dengan harga jual sebesar Rp. 105.000/sak nya. Dengan adanya subsidi ini petani dapat mengalihkan biaya produksi ke sarana produksi yang lainnya sehingga dapat mengoptimalkan produksi usaha tani. Hal ini sesuai dengan yang disampaikan oleh Keukama, M.F., dkk (2017) yang menyatakan agar dapat meningkatkan pendapatan usaha tani maka petani sebaiknya menekan biaya usaha taninya seminimal mungkin sambil berusaha meningkatkan hasil produksi usaha taninya.

Dengan hasil analisis yang menyatakan bahwa usaha tani padi pada penelitian ini layak, maka untuk itu perlu dianalisis komponen biaya yang mempengaruhi pendapatan petani tersebut. Dalam hasil analisis untuk melihat faktor yang mempengaruhi pendapatan usaha tani padi ciherang, maka didapatkan hasil analisis sebagai berikut:

Tabel 2. Hasil Analisis Regresi Pendapatan Usaha Tani Ciherang

\begin{tabular}{lrrrr}
\hline \multicolumn{1}{c}{ Variable } & Coefficient & Std error & \multicolumn{1}{c}{ t } & \multicolumn{1}{c}{ sig } \\
\hline Constant & 25547149.499 & 792474.121 & 32.237 & .000 \\
B. Tenaga Kerja & 2.933 & .919 & 3.193 & $.003^{*}$ \\
H. Pupuk Phonska & .883 & .632 & 1.397 & .173 \\
H. Pupuk SP & 7.812 & 7.423 & 1.052 & .301 \\
H. Pupuk KCl & -6.255 & 2.622 & -2.386 & $.024^{*}$ \\
H. Pestisida & -1.267 & 1.584 & -.800 & .430 \\
Luas Lahan & -2717247.773 & 2035766.720 & -1.335 & .192 \\
H. Pupuk Urea & -43.161 & 20.816 & -2.073 & $.047^{*}$ \\
H. Pupuk ZA & .261 & 1.202 & .217 & .830 \\
H. Benih & -38.315 & 33.901 & -1.130 & .267 \\
\hline R-Square & .507 & \multicolumn{3}{c}{ F.Stat } \\
\hline Adj. R-Squared & .359 & \multicolumn{3}{c}{ Sig } \\
\hline
\end{tabular}

Keterangan: * signifikan pada $\alpha=5 \%$

Berdasarkan hasil estimasi pada tabel diatas maka persamaan yang dihasilkan sebagai berikut:

$$
\begin{aligned}
& Y=25.547 .149,499+2,933 X_{1}+ \\
& 0,883 X_{2}+7,812 X_{3}-6,255 X_{4}- \\
& 1,267 X_{5}-2.717 .247,773 X_{6}- \\
& 43,161 X_{7}+0,261 X_{8}-38,315 X_{9}
\end{aligned}
$$


Dari model persamaan diatas maka didapatkan koefisien determinasi sebesar 50,7 \% yang menunjukkan bahwa sebesar $50,7 \%$ variasi variabel pendapatan petani ciherang dapat dijelaskan oleh variabel-variabel yang diteliti yaitu biaya tenaga kerja, biaya pupuk phonska, biaya pupuk SP, biaya pupuk $\mathrm{KCl}$, biaya pestisida, luas lahan, biaya pupuk urea, biaya pupuk ZA dan biaya benih. Sisanya sebesar $49,3 \%$ dijelaskan oleh variabel diluar model yang diuji yaitu harga jual, efisiensi teknik produksi dan variabel lainnya.

Berdasarkan hasil analisis fungsi pendapatan, maka diketahui variabel yang berpengaruh secara signifikan terhadap pendapatan adalah variabel biaya tenaga kerja, harga pupuk $\mathrm{KCl}$ dan harga pupuk urea. Varibel harga pupuk phonska, harga SP, harga pestisida, luas lahan, harga pupuk ZA dan harga benih tidak berpengaruh secara signifikan terhadap pendapatan yang di tunjukkan dengan nilai t-hitung lebih kecil dari nilai ttabel. Berikut penjelasan dari variabel-variabel yang diuji pada fungsi pendapatan:

a. Biaya tenaga kerja

Variabel biaya tenaga kerja berpengaruh signifikan dan positif terhadap pendapatan usaha tani Ciherang. Dimana ketika biaya tenaga kerja bertambah maka pendapatan petani akan meningkat, hal ini sesuai dengan penelitian Lampaga (2015) yang di lakukan di Kecamatan Sigi Biromaru menunjukkan bahwa bertambahnya jumlah tenaga kerja akan mendorong pengolahan usaha tani yang intensif Pada pengelolaan usaha tani di Desa Tebing Tinggi para pemilik sawah menggunakan tenaga kerja luar keluarga untuk melakukan kegiatan usaha tani, yang dimulai dari pengolahan lahan, membentengi, penanaman, penyiangan, pemupukan, pemyemprotan dan panen. Hal ini dilakukan karena luas lahan yang dimiliki oleh petani rata-rata $2 \mathrm{Ha}$ dan pada umumnya di desa tersebut banyak masyarakat yang berkerja sebagai buruh tani. Adapun upah yang diberikan kepada tenaga kerja luar keluarga sangat bervariasi tergantung jenis pekerjaan yang dilakukan. Kegiatan yang banyak mengeluarkan biaya adalah kegiatan pemupukan sebanyak tiga kali dan penyemprotan sebanyak enam kali dimana setiap 1 HOK dibayar Rp. 100.000,-. Untuk itu pada tabel 1 dapat dilihat biaya variabel merupakan biaya terbesar dimana biaya tenaga kerja merupakan bagian didalamnya yang menyusun komponen biaya tersebut.

b. Harga pupuk phonska

Variabel harga pupuk phonska tidak berpengaruh signifikan terhadap pendapatan usaha tani Ciherang. Petani tetap menggunakan phonska untuk meningkatkan produksinya karena harga pupuk phonska 
yang masih terjangkau di desa ini dengan harga Rp. 135.000/saknya. Petani dengan luas lahan $1 \mathrm{Ha}$ menggunakan pupuk phonska sebanyak 7 sak dalam 1 musim tanam, hal ini menunjukkan bahwa harga pupuk phonska tidak menjadi masalah bagi petani dan pupuk ini merupakan pupuk pelengkap yang digunakan petani. Riyastani, dkk (2013) dalam penelitiannya menyatakan bahwa dosis penggunaan pupuk yang dianjurkan sebanyak 125-150 $\mathrm{Kg} / \mathrm{Ha}$ dimana fungsi pupuk ini untuk merangsang pertumbuhan dan perkembangan serta pembuahan yang lebih cepat. Sedangkan di daerah penelitian menunjukkan bahwa penggunaan pupuk phonska sangat berlebihan yaitu sekitar 7 sak atau 350 $\mathrm{Kg} / \mathrm{Ha}$.

c. Harga pupuk SP

Variabel harga pupuk SP tidak berpengaruh signifikan terhadap pendapatan usaha tani Ciherang. Penggunaan pupuk SP pada daerah penelitian sesuai dengan dosis yang dianjurkan yaitu sebanyak 2 sak atau $100 \mathrm{Kg} / \mathrm{Ha}$. Hal ini sesuai dengan penelitian yang dilakukan oleh Jamaluddin (2016) yang menyatakan bahwa pupuk SP tidak berpengaruh kepada pendapatan petani Kecamatan Bangkinang kabupaten Kampar karena pemakaian yang berlebihan. Namun pada daerah penelitian dosis yang digunakan telah sesuai karena disamping itu harga dari pupuk SP di daerah penelitian masih terjangkau oleh petani yaitu Rp. 130.000/sak nya.

d. Harga pupuk $\mathrm{KCl}$

Variabel harga pupuk $\mathrm{KCl}$ berpengaruh signifikan terhadap pendapatan usaha tani Ciherang. Petani dalam melakukan kegiatan usaha taninya menggunakan pupuk $\mathrm{KCl}$ untuk membuat tinggi tanaman sehingga jumlah anakan banyak. Besarnya jumlah penggunaan pupuk $\mathrm{KCl}$ rata-rata yaitu 2 sak atau $100 \mathrm{Kg} / \mathrm{Ha}$, sama halnya dalam penggunaan pupuk phonska. Namun harga pupuk KCl relatif lebih mahal dibanding pupuk yang lain yaitu sebesar Rp. $280.000 /$ sak, walau begitu petani tetap membeli untuk diaplikasikan di usaha tani nya. Berdasarkan penelitian Misran (2014) untuk mendapatkan pertumbuhan dan produksi yang optimal maka diberikan pupuk lengkap yaitu urea, SP36 dan KCl dengan potensi hasil sebesar $38,69 \%$ atau 6,13 ton/Ha gabah kering panen.

e. Harga pestisida

Variabel harga pestisida tidak berpengaruh signifikan terhadap pendapatan usaha tani Ciherang. Adapun jenis pestisida yang digunakan antara lain herbisida, insektisida, fungisida dan rodentisida dimana pengaplikasian dari ke empat jenis pestisida ini sebanyak enam kali dengan waktu penggunaan 
yang masing-masing berbeda. Dalam satu botol pestisida yang digunakan dapat diaplikasikan untuk dua sampai tiga kali musim tanam sesuai dengan kebutuhan umur tanaman sesuai dosis yang diperlukan sehingga petani bisa melakukan penghematan biaya dalam penggunaan pestisida. Oleh karena itu biaya pestisida tidak berpengaruh terhadap pendapatan petani dan petani dapat mengalokasikan ke sarana produksi lainnya.

f. Luas lahan

Variabel luas lahan tidak berpengaruh signifikan terhadap pendapatan usaha tani Ciherang. Hal ini disebabkan luas lahan yang luas tidak menjamin produksi yang tinggi dan dapat mendapatkan penerimaan yang tinggi pula. Terdapat beberapa petani yang memiliki luas lahan yang besar namun produksi yang dihasilkan tidak sebanding, bisa saja hal ini disebabkan oleh tidak efisiennya petani dalam melakukan kegiatan usaha taninya. Hal ini berbeda dengan yang dilakukan peneliti Saragih, F.H dan K. Saleh (2016) di Desa Sei Buluh Kecamatan Teluk Mengkudu, Deli Serdang yang menemukan bahwa luas lahan berpengaruh terhadap pendapatan petani. Dimana daerah penelitian ini merupakan daerah berdekatan dari lokasi penelitian yang dilakukan dan mempunyai karakterikstik lahan yang sama. Sehingga dapat diduga adanya ketidakefisienan dalam pengelolaan usaha taninya, namun dalam penelitian Zahara, dkk (2016) menemukan bahwa usaha tani di Kabupaten Pringsewu tidak mempunyai korelasi yang signifikan terhadap pendapatan usaha tani padi di daerah tersebut.

g. Harga pupuk urea

Variabel harga pupuk urea berpengaruh negative dan signifikan terhadap pendapatan usaha tani Ciherang. Pupuk urea merupakan jenis pupuk yang paling banyak digunakan oleh petani padi dengan harga pupuk yaitu Rp. 105.000/sak dengan jumlah pemakaian rata-rata sebesar 6 sak untuk satu musim tanam. Kebutuhan unsur hara terbesar terdapat pada urea sehingga petani banyak menggunakan pupuk urea. Pupuk urea juga merupakan salah satu jenis pupuk subsidi yang paling banyak dibutuhkan oleh petani tidak hanya usaha tani padi namun juga usaha tani non padi lainnya. Dalam penelitian Triadati, dkk (2012) menyatakan bahwa urea sudah menjadi kebutuhan pokok petani padi dikarenakan penggunaan urea akan berdampak langsung terhadap peningkatan produksi padi. Oleh karena itu ketersediaan pupuk subsidi urea di petani sangatlah penting sekali, dapat dilihat bahwa kenaikan harga dari 
pupuk urea kan menurunkan pendapatan usaha tani padi.

h. Harga pupuk ZA Variabel harga pupuk ZA tidak berpengaruh signifikan terhadap pendapatan usaha tani Ciherang. Rata-rata penggunaan pupuk ZA sama dengan penggunaan pupuk urea, namun harga pupukZA lebih murah bila dibandingkan dengan pupuk urea yaitu harganya Rp 100.000 Sak nya. Hal ini yang menyebabkan tidak adanya pengaruh terhadap pendapatan usaha tani. Pada penelitian Aqil dkk (2014), pada tanaman jagung pemberian pupuk ZA pada dosis $50 \mathrm{Kg} / \mathrm{Ha}$ sampai dengan 300 $\mathrm{Kg} / \mathrm{Ha}$ tidak berbeda nyata, namun pada penelitian yang dilakukan oleh Syafitri, Pranita P.Q dkk (2018) pemberian pupuk ZA sebanyak $100 \mathrm{Kg} / \mathrm{Ha}$ yang ditambah dengan biourine sapi dengan dosis 200L memberikan pengaruh yang nyata terhadap hasil dan panen padi pada parameter bobot segar tanaman dan gabah per rumpun.

i. Harga benih

Variabel harga benih tidak berpengaruh signifikan terhadap pendapatan usaha tani Ciherang. Harga benih yang harus dikeluarkan petani untuk setiap 1 kg benih adalah sebesar Rp. $2.000 / \mathrm{Kg}$ nya. Rata-rata penggunaan benih dari sampel sebanyak $63 \mathrm{Kg}$, dimana setiap 1 Ha padi membutuhkan $30 \mathrm{Kg}$ benih untuk ditanam. Hal ini sesuai dengan yang disampaikan oleh Listiani, R dkk (2019) dalam penelitiannya di Kabupaten Jepara, harga bibit murah karena adanya subsidi pemerintah sehingga petani sangat terbantu dalam pembiayaan pengadaan benih.

\section{SIMPULAN}

Dalam penelitian ini diketahui bahwa faktor-faktor yang mempengaruhi pendapatan usaha tani padi di Desa Tebing Tinggi Kabupaten Serdang Bedagai adalah biaya tenaga kerja, harga pupuk $\mathrm{KCl}$ dan harga pupuk urea, sedang variabel lain tidak berpengaruh. Hal ini menunjukkan dugaan bahwa adanya pengelolaan usaha tani yang tidak efisien, dimana petani sebenarnya dapat menghasilkan pendapatan yang lebih tinggi dibandingkan saat ini. Disamping itu pengadaan pupuk subsidi dan bantuan benih padi sangat membantu petani dalam pengurangan biaya usaha taninya sehingga dapat mengalihkan ke biaya usaha tani nya yang lain. Penggunaan tenaga kerja yang besar juga akan berakibat dalam penambahan biaya yang dikeluarkan petani.

\section{DAFTAR PUSTAKA}

Aqil, M., dkk. 2014. Analisis Status Hara Tanah dan Tanaman Pada Berbagai Tingkat Pemupukan Amonium Sulfat. Prosiding Seminar Nasional "Inovasi Teknologi Pertanian Spesifik Lokasi". 6-7 Agustus 2014 
Astuti. 2017. Analisis Produksi dan Pendapatan Usahatani Padi Sawah Metode System of Rice Intensification di Kecamatan Sindue Kabupaten Donggala. ejurnal Mitra Sains. Vol.5, No.1 Januari 2017:36-42

BPS Serdang Bedagai. 2018. Serdang Bedagai Dalam Angka 2018.

Ismail Z., Made A., Rustam A, 2017. Analisis Komparatif Usahatani Padi Sawah Yang

Menggunakan Varietas Ciliwung Dan Cigeulisdi Desa Tatakalai Kecamatan Tinangkung Utara Kabupaten Banggai Kepulauan.J. Agroland Vol 24, No, 1: 1-9 April 2017

Jamaluddin. 2016. Analisis Faktorfaktor Yang Mempengaruhi Produksi Padi Varietas Unggul Nasional Pada Sawah Tadah Hujan di Kecamatan Bangkinang Kabupaten Kampar. Jurnal Dinamika Pertanian. Vol. XXXII No.2 Agustus 2016: 107-114

Keukama, M.F., dkk (2017). Analisis Pendapatan Usahatani Padi Ciherang Dengan Menggunakan Sistem Tanam Legowo Jajar (2:1) (Studi Kasus di Subak Sengempel, Desa Bongkasa, Kecamatan Abiansemal, Kabupaten Badung). E-jurnal Agribisnis dan Agrowisata Vol. 6 No. 1. Januari 2017

Lampaga, DeisyeN.A. 2015. Analisis Produksi dan Pendapatan Usahatani Padi Sawah di Desa Sidondo 1 Kecamatan Sigi Biromaru Kabupaten Sigi. Jurnal Agroland Vol.22 No.2 : 147 153, Agustus 2015

Listiani, R., A. Setiyadi dan S.I. Santoso. 2019. Analisis Pendapatan Usahatani Padi di Kecamatan Mlonggo Kabupaten Jepara.
Jurnal Agrisocionomics Vol. 3 No. 1: 50-58, Mei 2019

Ma'ruf, M.I., C.A. Kamaruddin dan A. Muharief. 2019. Analisis Pendapatan dan Kelayakan Usahatani Padi di Kecamatan Pitu Riawa Kabupaten Sidrap. Jurnal Sosial Ekonomi Pertanian. Vol. 15, No. 3, Oktober 2019

Misran. 2014. Pengaruh Penggunaan Pupuk Terhadap Pertumbuhan dan Hasil Padi Sawah. Jurnal Dinamika Pertanian Vol. XXIX No. 2 Agustus 2014 (113-118).

Munizar, A dan D. Tangkakesalu. 2019. Analisis Pendapatan dan Kelayakan Usahatani Padi Sawah Sistem Hambur Benih Langsung di Desa Dolago Kecamatan Parigi Selatan Kabupaten Parigi Moutong. e-J. Agrotekbis Vol 7 No.1: 51-58, Februari 2019

Purba, R. dan Y. Giametri. 2017. Keragaan Hasil dan Keuntungan Usaha Tani Padi dengan Introduksi Varietas Unggul di Provinsi Banten. Jurnal Ilmu Pertanian Indonesia Vol 22 No.1: 13-19, DOI: 10.18343/jipi.22.1.13

Ratri, M.A., dan Yuliawati, 2019. Perbandingan Pendapatan Usahatani Padi Varietas Ciherang dan Mekongga Di Desa Rogomulyo. Jurnal Agritech Vol XXI No, 1 Juni 2019

Riefqi, A.R. dkk. 2017. Pengaruh Benih Padi (Oryza sativa L.) Bersubsidi Terhadap Produksi dan Pendapatan Petani Padi Sawah. Buletin Agrihorti 5 (1): 1-8

Riyastini, S.C., Sutopo dan S. Suratiningsih. 2013. Pengaruh Penggunaan Benih, Pupuk Phonska dan Tenaga Kerja Terhadap Pendapatan Petani Kedelai (Glycine Max) di Desa 
$\begin{array}{lcr}\text { Sidoharjo } & \text { Kecamatan } & \text { Pati } \\ \text { Kabupaten } & \text { Pati. } & \text { Jurnal }\end{array}$ Agromedia Vol. 31 No. 1 Maret 2013.

Saragih, F.H dan K. Saleh.2016. Faktorfaktor Yang Mempengaruhi Pendapatan Rumah Tangga Tani Padi (Studi Kasus; Debiroasa Sei Buluh Kecamatan Teluk Mengkudu Kabupaten Deli Serdang). Jurnal Agrica Vol. 9, No.2. Oktober 2016

Soekartawi. 1993. Prinsip Dasar: Agribisnis Teori dan Aplikasinya. PT. Raja Grafindo Perkasa. JakartaR

Syafitri, Pranita P.Q. dkk. 2018. Pengaruh Aplikasi Biourine Sapi dan Pupuk ZA Terhadap Pertumbuhan dan Hasil Produksi Tanaman padi Varietas Ciherang.
Jurnal Produksi Tanaman Vol.6 No.7 Juli 2018: 1506-1512

Tridiati., A.A. Pratama dan S. Abdulrachman. 2012. Pertumbuhan Dan Efisiensi Penggunaan Nitrogen Pada Padi (oryza sativa l.) Dengan Pemberian Pupuk Urea Yang Berbeda. Buletin Anatomi dan Fisiologi Vol. XX No.2, Oktober 2012: 1-14

Zahara., R. Mawardi dan A. Irawati. 2016. Analisis biaya, Pendapatan Dan Faktor-faktor Yang Berhubungan Dengan Pendapatan Usahatani Padi di Kabupaten Pringsewu. Prosiding Seminar Nasional Agroinovasi Spesifik Lokasi Untuk Ketahanan Pangan Pada Era Masyarakat Ekonomi ASEAN. 